\title{
Matar e, depois, morrer
}

\begin{tabular}{c} 
Gláucio Ary Dillon Soares \\
luperj \\
Presidente da Associação Brasileira de Ciência Política \\
\hline
\end{tabular}

\section{Resumo}

O objeto deste artigo é apresentar um trabalho baseado em dados publicados sobre um dos tipos de homicídio e suicídio, denominado H/S. Como conhecer algo, um drama, no qual os principais protagonistas estão mortos? A maneira de conhecer o H/S não partir de uma ampla teoria com nenhuma base empírico-factual, mas construir uma teoria baseada em dados empíricos. Uma vez que não há informação, pesquisas e dados sobre o H/S no Brasil, este artigo baseia-se em informações e referências internacionais.

Palavras-chave: Homicídio/Suicídio, violência, crime urbano, bancos de dados

\section{Abstract}

The aim of this article is tho present a work based on published data about one of the types of homicide and suicide, known as homicide/suicide, H/S. How to understand something, a drama, in wich the main actors are dead? The way to understand the H/S is not to begin based on a wide theory without factual. empirical basis, but to construct a theory based on empirical data. As there is not H/S information, researches or database in Brazil, this article is based on international information and references.
\end{abstract}

Key words: Homicide/Suicide, violence, urban crime, data base 
O objetivo deste artigo é apresentar um trabalho em grande parte baseado em dados publicados sobre um dos tipos de homicídio - e de suicídio -, conhecido como homicídio/suicídio ou, abreviando, H/S. ${ }^{1}$ Porém, o próprio homicídio/suicídio, ou H/S, tampouco é uma categoria homogênea. Acolhe muitos tipos e, por isso, as tentativas de explicá-lo como um tipo fracassaram.

A classificação mais elementar dos H/S distingue entre H/S e pactos suicidas. Segundo Berman (1996), não se trata de uma simples classificação: a presença de hostilidade entre os parceiros distingue bem um tipo do outro; além disso, os tipos também variam de acordo com o grau de dominação e de dependência. Podemos levar essa tipologia mais adiante, porque

- Há homicídios nos quais o suicídio não estava planejado, vindo depois em conseqüência do remorso;

- há pactos suicidas, nos quais uma pessoa, de acordo com a outra, a mata, para depois se suicidar;

- há H/S como unidade, na qual tanto o homicídio quanto o suicídio são planejados e executados.

$\mathrm{O} \mathrm{H} / \mathrm{S}$ pode ser estudado, conhecido e, até certo ponto, previsto e evitado. Para tal, é necessário ter num único banco de dados a respeito da vítima, do autor, da relação entre os dois e do contexto. No Brasil, essa base de dados unificada não existe, havendo obstáculos para construí-la. Por isso, teremos que nos basear em pesquisas realizadas em outros países. ${ }^{2}$

Como conhecer algo, um drama, no qual os principais protagonistas estão mortos? A maneira de conhecer os H/S não é partir de uma ampla teoria com pouca ou nenhuma base empírico-factual, mas chegar a uma teoria construíndo-a a partir dos dados. Codificando e sistematizando dados a respeito dos autores, depois das vítimas, depois das relações entre eles, depois da situação em que se encontravam, do contexto cultural e das armas utilizadas, é possível ter aproximações sucessivas, cada vez mais adequadas, a uma teoria que tenha um poder preditivo e explicativo satisfatório. O H/S, como outros atos violentos, coleta subsídios de disciplinas diferentes, não sendo propriedade de nenhuma. A disciplinarização do estudo da violência, inclusive H/S, implica conhecer menos, deixar mais sem explicação, maior erro de especificação. Comecemos perguntando se H/S apresenta uma importante característica de outros tipos de violência, que é uma certa estabilidade.

\footnotetext{
${ }^{1}$ A pesquisa dos homicídios/suicídios requer uma base de dados integrada, com dados sobre o autor, a(s) vítima(s) e as circunstâncias que, infelizmente, não existe no Brasil. Por isso, teremos que usar bases de dados de outros países.

${ }^{2}$ A multiplicidade e variedade dos países é um eficaz antídoto contra o etnocentrismo. Usaremos dados de vários países, inclusive Canadá, Estados Unidos, Finlândia, França, Grã-Bretanha, Japão, Suécia, entre outros.
} 
Em sua grande maioria, os fenômenos violentos variam relativamente pouco no tempo, alguns aumentando ou diminuíndo apenas $20 \%$ ou $30 \%$ em relação ao ano anterior, quando numericamente poderiam aumentar milhares de vezes.

\section{H/S como fenômeno estável}

Uma primeira característica do H/S é a sua estabilidade. Os $405 \mathrm{H} / \mathrm{S}$ levados ao conhecimento da polícia, entre 1973 e 1992, em cinco estados da Austrália foram analisados, permitindo várias conclusões: como acontece com outras mortes violentas, H/S é um fenômeno estável, variando pouco da ano a ano.

\section{FIGURA I}

A estabilidade dos Homicídios/Suicídios - Austrália 1973 a 1992 em números absolutos

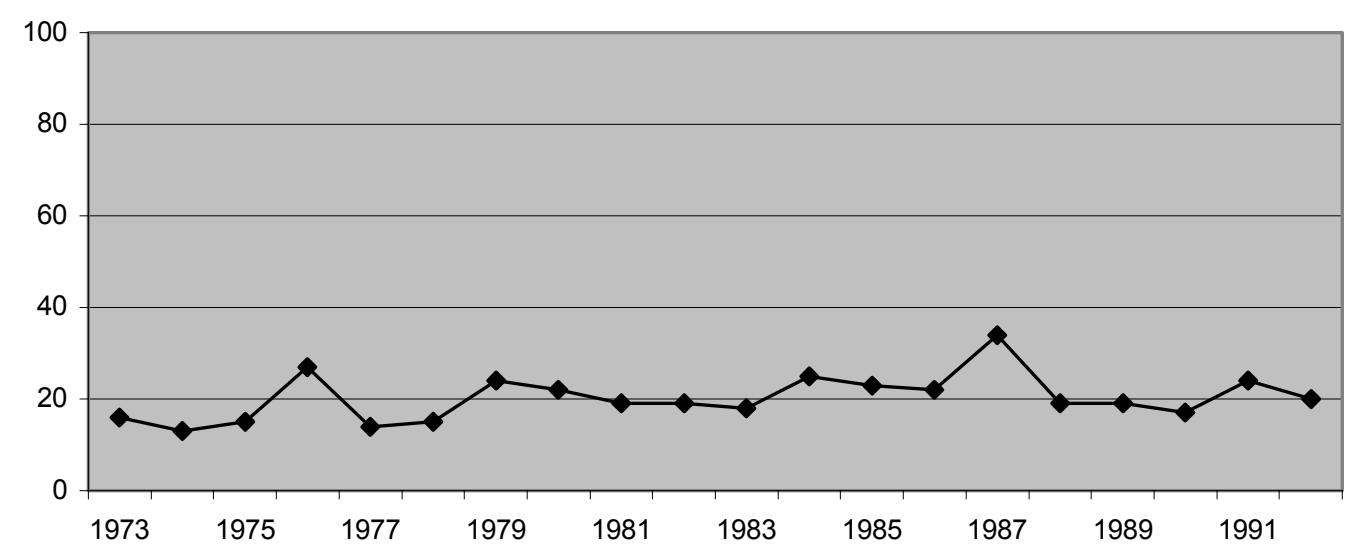

Estatísticas Descritivas da Figura I

\begin{tabular}{|ll|}
\hline Média & 20.25 \\
Erro padrão & 1,13 \\
Mediana & 19 \\
Moda & 19 \\
Desvio padrão & 5,06 \\
Variância & 25,6 \\
Kurtose & 1,44 \\
Skewness & 0,95 \\
Range & 21 \\
Minimo & 13 \\
Máximo & 34 \\
Soma & 405 \\
Casos & 20 \\
Nível de Confiança (0.950000) & 2,216 \\
\hline
\end{tabular}


No exemplo acima, referente a algumas províncias australianas, o número absoluto de H/S variou de um mínimo de 13 casos a um máximo de 34 - num período de vinte anos! Moda, média e mediana estão muito próximos.

Garantir que o fenômeno estudado é estável aumenta a confiança subjetiva na possibilidade de que seus determinantes também o sejam e de que os resultados de pesquisas realizadas em um ano possam ser aplicados, em maior ou menor medida, a outros.

Vejamos, agora, quais as regularidades encontradas nos homicídios. suicídios, os H/S.

\section{Gênero e $H / S$}

Jo Barnes avançou o conhecimento dos H/S com sua pesquisa na Austrália, cobrindo um amplo tempo, 1973-1992. Para isso, começou analisando as contribuições e limitações de cada perspectiva:

- Comparação de H/S com atos separados de homicídio, por um lado, e suicídio, por outro;

- $\quad$ Enfase em explicações psicológicas, baseadas em doença mental;

- Detalhamento do perfil das vítimas, dos assassinos, da relação entre eles e do contexto do crime.

Essas pesquisas permitiram algumas conclusões: H/S é um crime de gênero, uma vez que os homens são a ampla maioria dos assassinos e as mulheres e crianças conformam a ampla maioria das vítimas; é familiar ou "entre íntimos", porque as mulheres, em sua grande maioria, são vítimas de maridos, amantes, companheiros e namorados, e as crianças são vítimas dos seus pais ou dos parceiros(as) deles. Não obstante, Barnes considera importante salientar que homens brancos tendem a matar mulheres adultas e, ocasionalmente, seus(suas) filhos(as), ao passo que as mulheres, em sua grande maioria, matam apenas seus(suas) próprios(as) filhos(as).

Na Austrália e em vários outros países pesquisados, H/S é um crime de gênero. Os homens são a grande maioria dos assassinos, mas as mulheres são a maioria das vítimas: os homens representavam 90\% dos assassinos e $30 \%$ das vítimas. A média das idades diferia: os assassinos tinham, em média, 43 anos e as assassinas, 32. Os homens adultos vitimados também eram mais velhos: 43 anos, em comparação com 39 para as mulheres vitimadas. Vinte e oito por cento das vítimas tinham 15 anos ou menos de idade.

Em 1995, Felthous e Hempel fizeram uma revisão detalhada da bibliografia sobre H/S até aquela data, com um número grande de pesquisas feitas nos Estados 
Unidos, concluíndo que mais de $90 \%$ das pesquisas mostraram que os autores eram predominantemente homens, ao passo que entre $75 \%$ e $90 \%$ das vítimas eram mulheres.

O caráter de gênero de H/S transparece, também, em quem são as vítimas de assassinos homens e de assassinos mulheres. Homens e mulheres não matam o mesmo tipo de pessoas. A maioria dos homens mata suas mulheres e companheiras, ao passo que a maioria das mulheres mata seus próprios filhos:

FIGURA I/

Homicídio/Suicídio e Gênero - Austrália 1973 a 1992

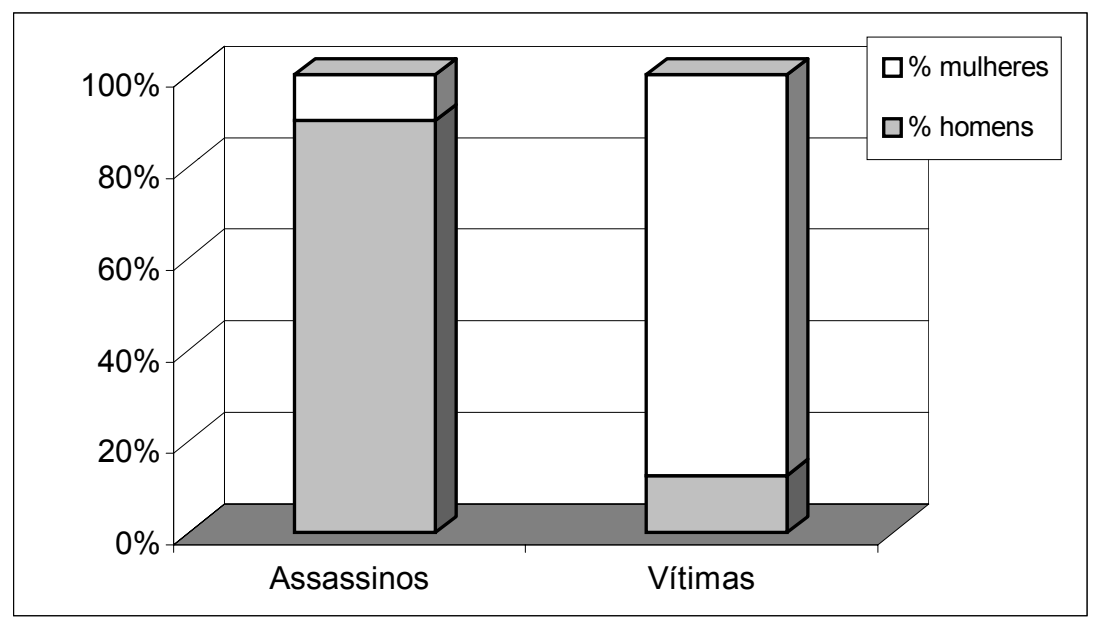

Os homens, quando mataram e se suicidaram, mataram suas companheiras, esposas ou namoradas em 54\% dos casos; em 24\%, seus filhos e filhas, e em $2 \%$, os enteados e enteadas. As mulheres mataram seus próprios filhos e filhas em $75 \%$ dos casos, e seus parceiros em apenas $17 \%$.

As vítimas que mantinham uma relação com o agressor representavam $40 \%$ de todas as vítimas, ao passo que as que haviam terminado a relação representavam $10 \%$. Sabemos que os homicídios de ex-parceiras, assim como os homicídios delas seguidos do suicídio do autor, ocorrem quase sempre durante a separação ou pouco tempo depois. Raramente acontece depois de um ano de separação. Como o número de ex-parceiras nessa fase é bem menor que o das que estão numa relação, sem qualquer relação, ou que terminaram a última relação há mais de um ano, podemos concluir que o período de ruptura e separação inicial é o mais perigoso do ponto de vista da mulher. 


\section{FIGURA III}

Vítimas de H/S por sexo do homicida - Austrália 1973 a 1992

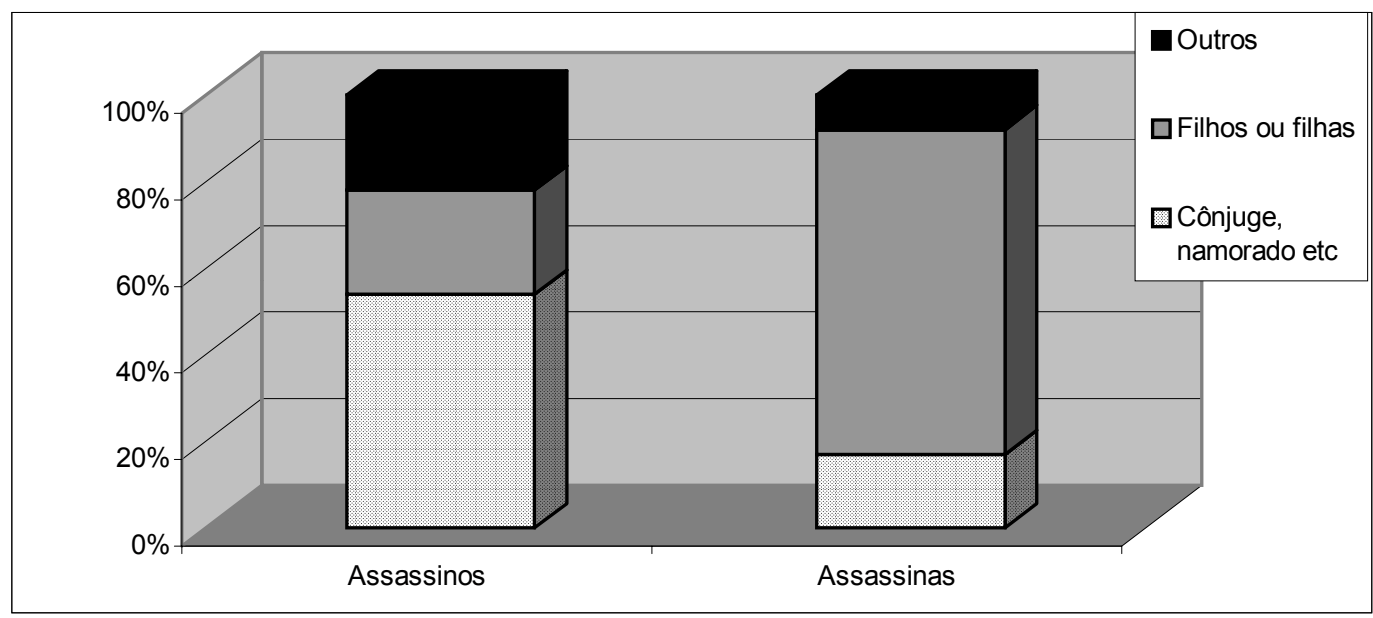

Um estudo dos homicídios/suicídios (H/S) em Paris, entre 1991 e 1996, revelou a existência de 56 casos, que produziram 133 vítimas (Lecomte \& Fornes, 1998). Em Paris, o homicídio intra-familiar foi o mais comum, seguido por pactos de suicídio. Nos H/S em família, a relação estava em estado caótico, sendo freqüentes as ameaças e a violência física. Nesses casos, com o ciúme e a possessividade masculina como combustível, o H/S não foi planejado, foi impulsivo, decidido no momento. O evento precipitador foi, na maioria dos casos, a ruptura da relação; em alguns casos, problemas financeiros e desemprego estiveram presentes. A existência de H/S foi definida quando alguém matava outrem e, em poucas horas, se suicidava. Para o estudo de Lecomte e Fornes, se o suicídio ocorresse um ou mais dias depois do homicídio, não estaria caracterizado um H/S. Dos 56 casos, 17 foram em Paris e 39 na sua vizinhança, uma taxa de 0,77 por 100 mil em Paris e de 0,45 na vizinhança. Oitenta e cinco por cento dos homicidas/suicidas eram homens, com a média de 51 anos para os homens (variando de 24 a 83) e de 40,5 para as mulheres (variando de 33 a 56). Os autores de H/S são um pouco mais velhos do que suas vítimas e também são mais velhos do que as autoras de H/S.

O condado de Dade, na Flórida, é conhecido pela sua alta percentagem de habitantes de origem hispânica. Entre 1957 e 1981, houve 133 casos de H/S, dos quais apenas 7,5\% foram cometidos por mulheres.

Aderibigbe (1997) estudou os H/S ocorridos nos Estados Unidos de 1990 a 1995, descritos nos principais jornais do país. Analisar jornais é uma estratégia que reduz os custos da pesquisa, mas aumenta a margem não-controlada de erro. Buscou informação sobre 300 homicidas que foram responsáveis por 734 mortes. Os resultados confirmaram o que sabíamos: os homicidas eram, em sua ampla 
maioria, homens; as vítimas eram, predominantemente, mulheres, parceiras e exparceiras sexuais, ou familiares.

O estudo de Kominato et al (1997) permite ver que, em Toyama, Japão, o homicídio é um fenômeno entre íntimos - $80 \%$ ocorrem na casa da vítima e apenas $5 \%$ são por roubo ou crime sexual. Dadas as percentagens, H/S é, também, um crime entre íntimos.

A maioria dos homicídios não produz o suicídio do autor. Não obstante, a percentagem de homicidas que depois se suicidam varia por país, por características do autor, da vítima e da relação entre eles. Em Toyama, 27\% dos homicídios ocorridos em 10 anos foram H/S. Chama a atenção o fato de que, em dez anos, pouco mais de sessenta homicídios foram cometidos. O Japão, com leis e cultura contra armas de fogo, tem uma das taxas de homicídio mais baixas do mundo. A de Toyama é 0,55 por 100 mil habitantes.

Bourget et al analisaram os homicídios e suicídios em Quebec, de 1991 a 1998. De 387 casos estudados, 37\% foram homicídios de cônjuges; em 40\% destes casos, o(a) esposo(a) assassino(a) se suicidou depois. Como em outros lugares, a maioria absoluta dos homicidas era de homens, separados da mulher ou companheira, tendo usado arma de fogo tanto para matar quanto para se suicidar ${ }^{1}$. A maioria exibia, também, sintomas clínicos de depressão.

Morton et alii (1998) estudaram 119 casos de vítimas mulheres de H/S na Carolina do Norte entre 1988 e 1992. Os resultados confirmam as pesquisas anteriores realizadas em vários tempos e lugares: em $78 \%$ dos casos o homicida é o atual ou o ex-parceiro da vítima. Um em cada quatro assassinos que mataram suas parceiras se suicidou depois, e outros $3 \%$ tentaram suicídio, mas sobreviveram à tentativa ${ }^{3}$.

\section{FIGURA IV}

Relações entre agressor e vítima, casos de H/S - Carolina do Norte 1988 a 1992

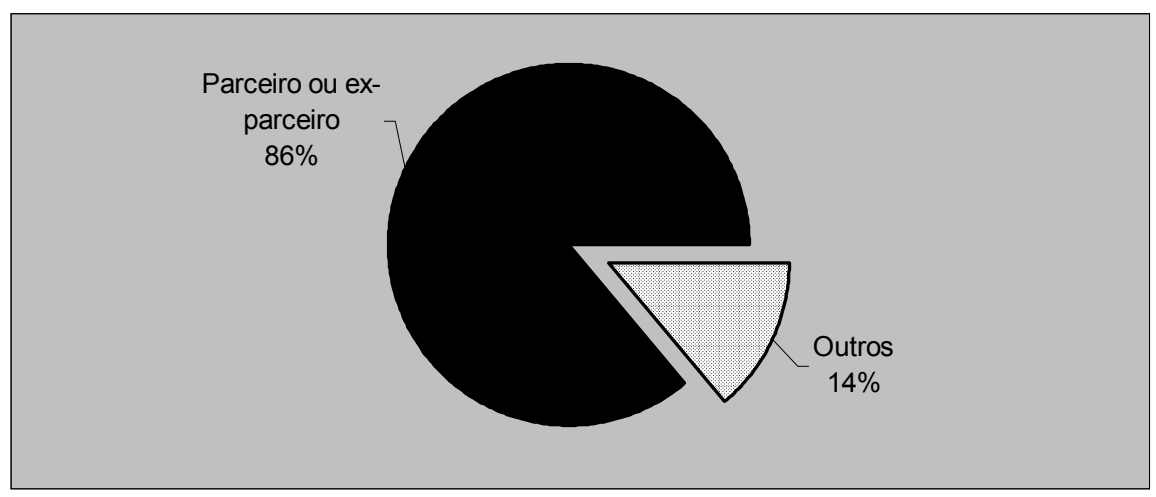

\footnotetext{
${ }^{3}$ Em metade dos casos, a vítima procurara auxílio das autoridades, o que depõe contra a qualidade e a sensatez dos serviços policiais e sociais do estado.
} 
O desespero que freqüentemente acompanha tais casos produz outras vítimas: no estudo citado, em $43 \%$ dos casos uma ou mais crianças da vítima e/ou do assassino testemunharam o H/S, estavam próximas do local, descobriram os corpos dos pais ou foram mortos. Só podemos imaginar o peso psicológico que essas crianças carregarão para o resto das suas vidas.

\section{Aspectos culturais e sociais: a imigração e minorias}

A Austrália, onde foram realizados vários estudos de H/S, é um país de imigrantes, muitos dos quais são de primeira ou segunda geração. Uma em cada quatro pessoas que vivem na Austrália nasceu fora dela. Evidentemente, esse é um aspecto que, na análise da Austrália, não pode ser ignorado. Há ampla literatura demográfica e sociológica que mostra que os emigrantes são selecionados, isto é, não são uma amostra aleatória da população de onde saíram e que os imigrantes tampouco são uma amostra aleatória da população do país para o qual migraram. Mostra, também, que os imigrantes experimentam vários fatores de estresse, muitos dos quais associados à própria imigração. Assim, os imigrantes se diferenciam da população de destino pelas influências culturais que tiveram antes da imigração, que os australianos não tiveram, pela experiência da imigração, que os australianos também não tiveram, e pelo status social e étnico na Austrália, que também difere do dos australianos. Como as três condições se apresentam juntas em todos os imigrantes, não temos como separar a influência de cada uma delas. Assim, o único contraste com os dados publicados é o que se verifica entre imigrantes e australianos de nascimento.

\section{FIGURA $V$}

\% de imigrantes em diferentes grupos na Austrália

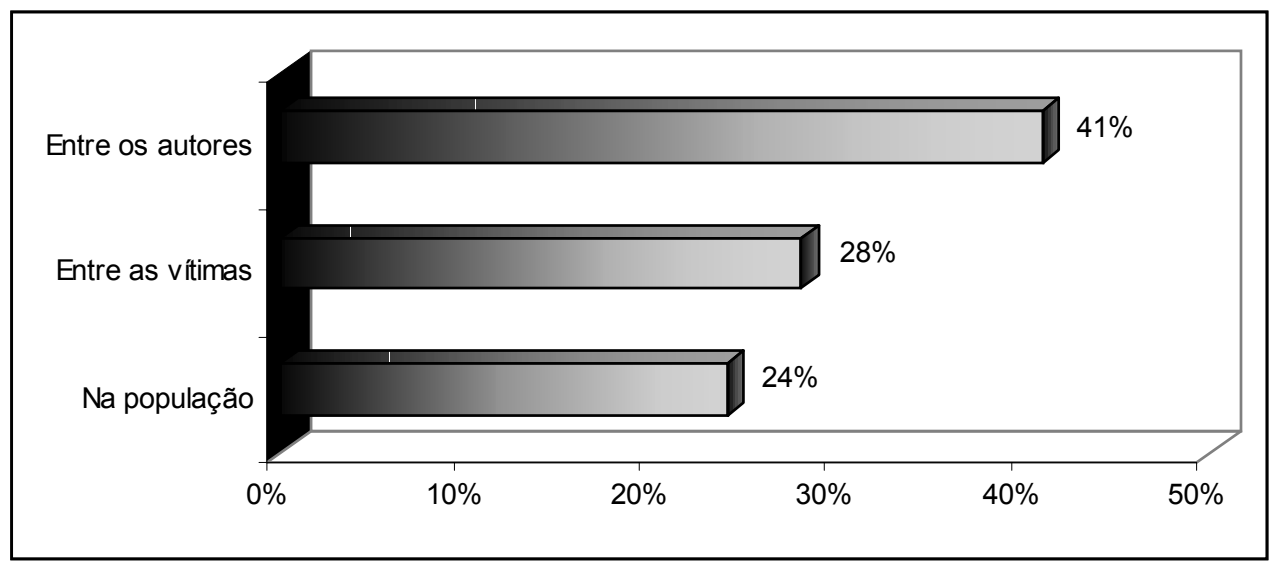


Barnes salientou que os australianos de nascença representam $76 \%$ da população, mas apenas $59 \%$ dos autores. Isso significa que seria difícil classificar os H/S como um fenômeno tipicamente australiano. Repetindo, é impossível saber se a sobre-representação dos imigrantes deriva da(s) cultura(s) que trazem consigo ou das dificuldades inerentes à imigração. Precisaríamos conhecer as taxas equivalentes nas culturas de origem, controlando pelos fatores que influenciam esse resultado - gênero, estado civil, idade etc.

Outro estudo, também realizado na Austrália, sublinha que a população aborígene tem taxas mais altas de risco de homicídio "entre íntimos" (Easteal, 1994). A existência de altas taxas de violência em minorias historicamente subjugadas (aborígenes, indígenas, negros escravizados etc.) tem sido confirmada por várias pesquisas em países e momentos diferentes. Um relatório recente, de 2001, sobre os aborígenes australianos, incluiu extensa revisão do que estava publicado e análises de dados mostram taxas de violência doméstica, homicídio, suicídio, violência contra crianças, assim como de alcolismo superiores à média nacional (Memmott; Stacy; Chambers, et. al., 2001) Outro estudo compara taxas de violência em populações indígenas na Austrália e nos Estados Unidos com as respectivas populações totais, chegando à conclusão de que são substancialmente mais altas - duas a três vezes mais altas (Stevenson, Wallace, Harrison, Moller \& Smith, 1998). As altas taxas de homicídios entre íntimos sugere que as taxas de $\mathrm{H} / \mathrm{S}$ também são mais altas.

\section{Os instrumentos da morte}

As armas usadas em homicídios-suicídios também se relacionam com o gênero, mais do que no homicídio simples. Entre os homens, tres entre cada quatro usaram armas de fogo para matar (73\%) e para o suicídio (74\%). Em geral, a mesma arma foi usada. Já entre as mulheres (que mataram predominantemente seus próprios filhos e filhas), as armas de fogo foram muito menos usadas, tanto no homicídio (15\%), quanto no suicídio (17\%). Monóxido de carbono ou asfixia foram usados em $39 \%$ dos homicídios e $28 \%$ dos suicídios. A extensa revisão de Felthous et al mostra que, desde a década de 60 , as armas de fogo são o instrumento mais usado nos casos de H/S e que a residência da vítima ou do autor são os locais onde os homicídios/suicídios acontecem com mais freqüência. Em diferentes países, a conclusão é a mesma: a presença de arma na casa multiplica a probabilidade de homicídios/suicídios.

Como em outros países, Lecomte e Fornes mostraram que as armas de fogo foram usadas na clara maioria dos H/S em Paris: em 80\%. Pistolas e revólveres dominaram, ainda que menos do que nos Estados Unidos, 26 contra 19 de rifles, espingardas e carabinas. Em apenas nove casos a arma usada para matar as 
vítimas foi diferente da usada no suicídio. Facas e estrangulamento foram usadas em quatro casos cada. Em $71 \%$ dos casos, o assassino matou uma pessoa e em 29\%, mais de uma, antes de se suicidar.

No estudo de Aderibigbe (1997) que cobriu os H/S ocorridos nos Estados Unidos de 1990 a 1995, o instrumento, em 90\% dos casos, foi uma arma de fogo. Graser demonstrou, em seu estudo de H/S na África do Sul, que as armas de fogo são as mais usadas em H/S. Milroy no seu estudo comparativo, internacional, de H/S também sublinhou a altíssima representação das armas de fogo (Milroy, 1995), ao passo que Adler (1999) enfatizava que em Chicago, na passagem do Século XIX para o XX, as armas de fogo eram mais usadas em H/S do que em suicídios.

\section{FIGURA VI}

\section{Percentagem de autores de $\mathrm{H} / \mathrm{S}$ usando armas de fogo}

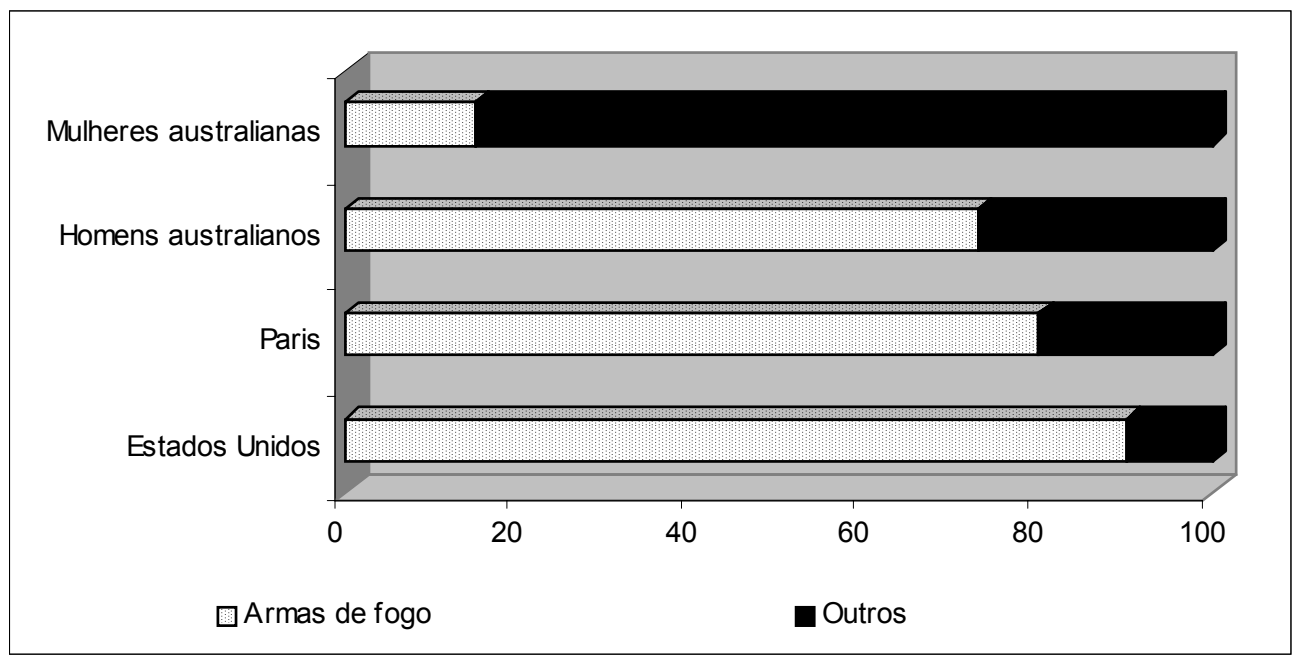

Em Paris, uma nota de suicídio foi encontrada em metade dos casos. Em $75 \%$ o assassino/suicida estava seriamente deprimido o que, mais uma vez, deve colocar a sociedade e os serviços de saúde, particularmente mental, de sobreaviso em relação aos que sofrem de séria depressão. O alcoolismo crônico estava presente em $29 \%$ dos casos. A presença de uma arma de fogo na casa foi um fator que contribuiu muito para o desenlace. O quadro modal é o de um homem de meia idade, deprimido, violento e ciumento, que usa arma de fogo para matar a sua companheira e, às vezes, as crianças da casa e até os animais. Na maioria dos casos, houve "aviso", na forma de ameaças e violência.

Lecomte e Formes concluíram que H/S é um processo claramente diferente tanto de homicídio quanto de suicídio. Apresenta antecedentes e dá aviso, o que permite a prevenção. 


\section{Uxoricídio, filicídio, familicídio e $\mathrm{H} / \mathrm{S}$}

O assassinato de cônjuges, sobretudo de esposas e companheiras, é a forma mais comum de H/S. Porém, há diferenças entre "homens que matam a parceira" e "homens que matam a parceira e se suicidam", entre uxoricídio e H/S. Não obstante, é possível aprender algo a respeito de H/S examinando o assassinato de cônjuges e parceiras(os). Não devemos esquecer que, em alguns casos de H/S, há indicações de que o que começou como uxoricídio se transformou em H/S. Não foi planejado assim, mas terminou assim. Essas indicações se baseiam em documentos escritos - alguns dos quais fazem menção a suicídio e outros não -, informações de terceiros, e testemunhos ocasionais de expressões e confissões do autor entre o uxoricídio e o suicídio.

Há instâncias em que um dos membros da família mata mais de um dos demais membros. Na definição técnica, usada por Wilson et al (1995), familicídio se refere a eventos em que um dos parceiros sexuais (cônjuge, namorado etc.) mata o outro e, além disso, mata um ou mais dos filhos. Os pesquisadores analisaram 109 casos de familicídio no Canadá e na Grã-Bretanha.

Há alguns padrões: quase todos os familicídios foram de autoria de homens, como diferente de outros tipos de homicídio intra-familiar, como o uxoricídio e o filicídio nos quais há uma percentagem maior de autoras, . Nada menos do que metade dos autores se matou também, uma taxa muitíssimo mais alta do que a taxa de suicídios entre uxoricidas e filicidas. É interessante sublinhar o efeito do matrimônio legal: as uniões consensuais estavam sobre-representadas entre os familicídios, em comparação com a percentagem de uniões consensuais na população. Não obstante, as uniões consensuais estão ainda mais representadas nos uxoricídios "simples", em que inexistem outras vítimas. Como acontece com assassinatos "simples" de menores, enteados e enteadas estão sobre-representados entre as vítimas em relação ao seu número na população total. Não obstante, a sobre-representação de enteados e enteadas nos filicídios "simples" é ainda mais alta. Os homens que matam seus enteadas e enteados diferem dos que matam seus próprios filhos: no primeiro caso - enteados - poucos se suicidam, ao passo que uma percentagem muito mais alta dos pais naturais se suicida após matar seus próprios filhos.

Em quase todas as pesquisas, a maior freqüência de H/S era contra cônjuges e parceiras ou ex-parceiras sexuais e sentimentais. A França se constitui numa exceção: em Paris e sua vizinhança, as vítimas de $\mathrm{H} / \mathrm{S}$ são predominantemente crianças. Foram 34, 21 meninos e 13 meninas, cuja idade média era de 8 anos. Seguiram-se 29 cônjuges (26 esposas); duas namoradas; dez desconhecidas(os) e dois parentes. Nesse evidente ato de desespero, até animais domésticos foram mortos: cinco. 
Um estudo na Finlândia pesquisou todos os assassinatos conhecidos de menores de 12 anos por suas mães, entre os anos 1970 e 1996. Localizaram quarenta e oito mães que mataram seus filhos. Não é uma ocorrência comum na Finlândia, embora talvez seja sub-enumerada devido à relativa facilidade em ocultar um assassinato de menor. Com a maior divulgação de sinais de homicídio proporcionados pela medicina forense, é possível que o número diminua, devido à crescente probabilidade de detecção e condenação. Foram 15 neonaticídios, definidos como bebês de um dia ou menos, e 33 maiores de um dia e menores de 12 anos. Com base no Exame do Estado Mental, feito naquele país, e em análise qualitativa de todo o material disponível, as autoras propõem seis tipos de homicídios:

- Neonaticídios

- depressão pós-parto

- agressão impulsiva

- atos psicóticos
- atos abusivos e

- tentativas de homicídio/suicídio

Os neonaticídios eram, usualmente, cometidos por mães jovens, solteiras e dependentes da família, que tinham menos problemas psicológicos do que as que matavam crianças mais velhas; as mães que matavam filhos mais velhos tinham um perfil diferente: a maioria era casada, havia maior percentagem com sintomas de depressão e com histórico de atos impulsivos e agressivos. Havia problemas situacionais, sobretudo estresse na família, com mais freqüência (Haapasalo et al, 1999).

\section{TABELA I}

Comparação de algumas características de autoras de $H / S$ e de Suicidas Condado de Dade, Flórida, 1957 a $1981^{4}$

\begin{tabular}{|l|l|l|}
\hline Características & Autoras de H/S & Suicidas \\
\hline Presença de depressão & Menos & Mais \\
\hline Viver em trailers & Mais & Menos \\
\hline Viver só & Menos & Mais \\
\hline
\end{tabular}

A comparação de mulheres que mataram e depois se suicidaram, com as que se suicidaram sem matar ninguém, mostra algumas diferenças: Havia mais alta percentagem de suicidas que viviam sós, do que autoras de H/S; mais suicidas estavam deprimidas e uma percentagem menor vivia em trailers, que é um indicador de baixo status sócio-econômico.

\footnotetext{
${ }^{4}$ Tabela construída com dados de Fishbain David A; Rao Valerie J; Aldrich Tim E. "Female homicide-suicide perpetrators: a controlled study” Journal of Forensic Sciences, 30, (4), 1985, págs. 1148-1156.
} 
No caso de pessoas que matam os seus próprios filhos, parece claro que a culpa e a probabilidade de que o homicídio seja seguido de suicídio aumenta com a idade da vítima. A verdade infeliz parece ser que os recém-nascidos não têm cidadania, nem plena proteção aos olhos da lei e da sociedade (Silverman, 1988). Matar um recém-nascido é considerado "menos" crime do que matar uma criança ou um adolescente.

Previsivelmente, os meios mudam com a idade das vítimas. As mães que mataram bebês os estrangularam ou asfixiaram em $40 \%$ dos casos, usando outras técnicas em 32\%. As mães que mataram crianças (e não bebês), em sua maioria, os mataram com pancadas. Isso configura a alta probabilidade de que uma percentagem significativa desses infanticídios seja uma extensão de abuso de crianças. Levanto a hipótese de que, em não poucos desses casos, o objetivo era bater, punir, mas a criança morreu em conseqüência da pancadaria.

\section{FIGURA VII}

Infanticídio pela mãe, com e sem suicídio posterior, por idade da vítima - Canadá 1961 a 1983

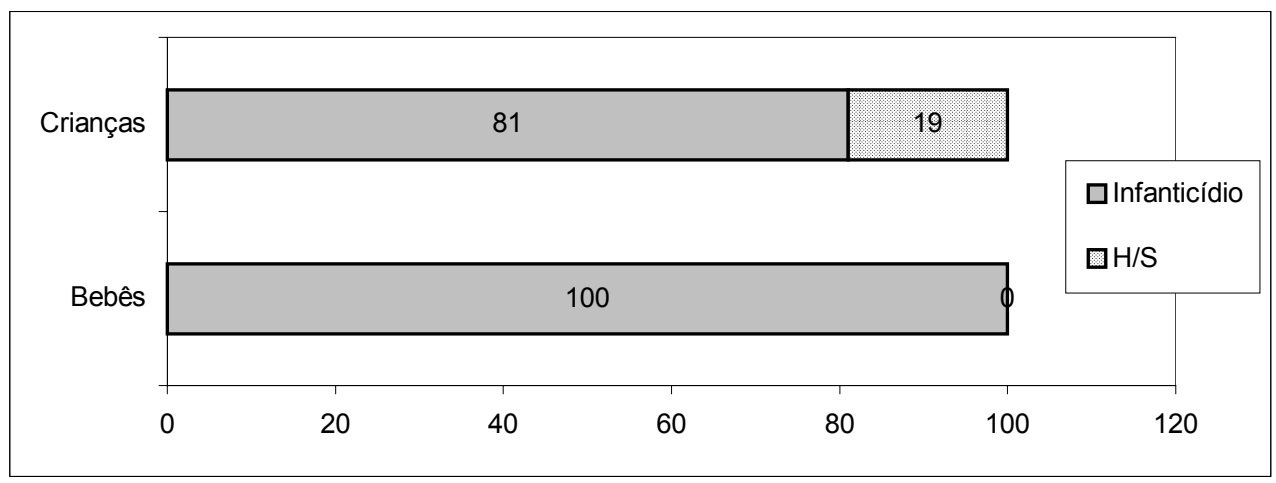

TABELA //

Diferenças entre mães que matam bebês e crianças ou adolescentes

\begin{tabular}{|l|l|l|}
\hline Características & Bebês & Crianças e adolescentes \\
\hline Estado civil da mãe & Mais solteiras & Mais casadas e unidas \\
\hline Suicídio da mãe & Raro & Mais freqüente \\
\hline Diagnóstico de doença mental & Infreqüente & Freqüente \\
\hline Métodos & Asfixia, estrangulamento & Pancadas \\
\hline
\end{tabular}


Infanticídios e assassinatos de crianças não são amostra aleatória do total de homicídios. Um estudo de mais de 30 mil homicídios, cometidos na Califórnia entre 1981 e 1990, revelou que, em comparação com os homicídios de adultos, havia muitas diferenças significativas.

Os dados de Chew et alii mostram que homicídios de menores de 15 anos se associam mais com H/S do que homicídios de adultos; porém, outras pesquisas mostraram que o homicídio de bebês se associa menos com $\mathrm{H} / \mathrm{S}$ do que o homicídios de crianças e adolescentes. Isso sugere a presença de, no mínimo, três tipos de homicídio, com diferentes características, definições sociais e probabilidade de H/S.

\section{TABELA III}

Características de 30.929 homicídios na Califórnia, 1981 a 1990, adultos e menores 5

\begin{tabular}{|llll|}
\hline \multicolumn{1}{|c|}{ Características } & \multicolumn{1}{c|}{ Adultos } & \multicolumn{1}{c}{ Menores de 15 anos } \\
\cline { 1 - 1 } $\begin{array}{l}\text { O autor é um desconhecido } \\
\text { ou apenas um conhecido }\end{array}$ & Maioria & Minoria \\
O autor é um familiar & Minoria & Maioria \\
Composição étnica & Mais hispânicos e negros & Igual à da população \\
Dias com maior número & Fins de semana & Meio da semana \\
Horas com maior número & Noite e madrugada & Meio do dia \\
Local mais freqüente & Fora de casa, lugar público & Em casa \\
Razão ou tipo & Assalto ou briga & Abuso de crianças ou H/S \\
\hline
\end{tabular}

Martin Daly e Margo Wilson (1987) são dois dos maiores expoentes da escola sócio-biológico-evolucionista na Criminologia. Reviram um estudo anterior, de assassinato de menores em 60 sociedades, a partir de descrições etnográficas, além de 86 ocorrências no Canadá de 1974 a 1983. Seus resultados se encaixam com os de outros pesquisadores, ainda que suas conclusões possam diferir. Sumarizando seus resultados:

- A probabilidade de filicídio diminui com a idade do(a) filho(a) e a dos pais;

- A probabilidade de suicídio após o filicídio aumenta com a idade do(a) filho(a) e

- $\quad$ Crianças vivendo com padrastos e madrastas têm um risco muito maior do que as que vivem com seus pais naturais.

\footnotetext{
${ }^{5}$ Quadro construído a partir de dados de Chew Kenneth SY; McCleary Richard; Lew Maricres A, et. al. ’The epidemiology of child homicide in California, 1981 through 1990". Homicide Studies, 3, (2), 1999, págs. 151-169.
} 


\section{De homicídio a homicídio/suicídio: o papel dos vínculos pessoais e sociais}

Henry e Short (1954), num dos clássicos da criminologia, sugeriram que a probabilidade de suicídio em seguida ao homicídio aumentaria com os vínculos pessoais com a vítima e sociais com a sociedade. Henry e Short retiveram bastante da perspectiva durkheimiana, relacionando os dois fenômenos à anomie. Enfatizaram, também, numa perspectiva psicanalítica, a idéia de agressão como subjacente tanto ao suicídio quanto ao homicídio. Steven Stack, um dos principais criminólogos contemporâneos, testou essa hipótese num estudo de 16245 homicídios cometidos na área de Chicago, no período 1965-90. Usando técnicas multivariadas, Stack (1997) pôde concluir que a percentagem de suicidas variava com a relação do assassino com a vítima. Igualando a um a taxa dos que se suicidavam após o homicídio de uma pessoa estranha, Stack verificou que as probabilidades variavam muito e que os(as) assassinos(as) de ex-cônjuges e exparceiras(os) tinham uma probabilidade muito mais alta.

Os dados mostram que os que mataram um amigo ou amiga tinham quase o dobro da probabilidade de se suicidar do que os que mataram desconhecidos; já os que mataram as(os) namoradas(os) tinham uma probabilidade seis vezes maior; o assassinato de um cônjuge levou ao suicídio oito vezes mais do que o assassinato de uma pessoa desconhecida. Quando a vítima era filho ou filha, a probabilidade de suicídio era dez vezes maior, mas a mais alta probabilidade de suicídio estava associada ao homicídio de ex-cônjuges, ex-parceiras(os) e ex-namoradas(os).

\section{FIGURA VIII}

Probabilidade de suicídio do assassino por relação com a vítima de assassinato: desconhecido $=1$ (Chicago 1965 a 1990)

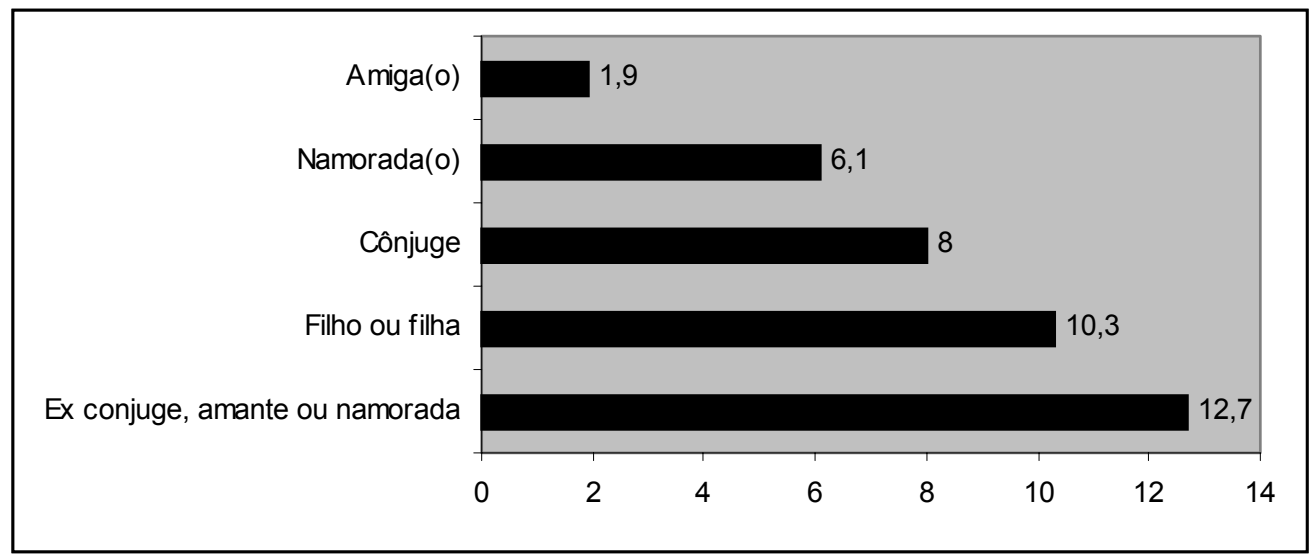


Repito que não estamos falando da probabilidade de homicídio, mas de H/S, de suicídio após o homicídio. Se o nível de intimidade e de parentesco fosse o único determinante da culpa que levaria ao suicídio, é difícil ver como ex-cônjuges e ex-namoradas produziriam mais culpa. Saliento duas interpretações plausíveis:

1. a percentagem das mortes de cônjuges que são atos de desamor e hostilidade, e não de amor frustrado e/ou ciúme, é mais alta do que de exparceiras(os);

2. uma das motivações para o homicídio é o sentimento possessivo em relação ao cônjuge, que é realçado quando a ruptura se deve à ex (parceira, namorada, esposa etc). Esse grupo, possivelmente, conta com maior número de tragédias em que a infidelidade, que fere o amor e desafia a propriedade, está presente.

Esses dados ilustram o caráter íntimo e relacional do suicídio após o homicídio. Quanto mais íntima a relação entre assassino e vítima, maior a probabilidade de suicídio do assassino. Porém, o sentimento de propriedade perdida ou em vias de se perder parece pesar tanto na decisão de matar quanto na de se suicidar.

No Canadá, Gillespie et al (1998) partiram dessa hipótese, ao analisar 5.408 homicídios cometidos por homens entre 1961 e 1983. A probabilidade de que o autor se suicidasse após o homicídio aumentava com o grau de intimidade com a vítima, o que confirma os resultados de Stark. Gillespie e colaboradores também descobriram que a probabilidade de suicídio aumentava com a idade e a educação do assassino. A probabilidade era ainda mais alta se se tratasse de uma assassina. O uso de arma de fogo também aumentava a probabilidade de suicídio.

Qual a percentagem dos homicídios que terminam em suicídio dos autores? Os dados disponíveis não são diretamente comparáveis, mas proporcionam uma idéia dos parâmetros.

Os dados sobre a percentagem dos homicídios que são H/S encontram dificuldades de interpretação porque os totais diferem. Na Grã-Bretanha e em Toyama são sobre o total de homicídios; em Quebec se refere a homicídios entre cônjuges e na Austrália entre cônjuges e parceiros; finalmente, na Carolina do Norte, os totais se referem a vítimas mulheres ou parceiras. Os filicídios estão excluídos em Quebec, Austrália e Carolina do Norte. O estudo da Carolina do Norte exclui, ademais, maridos e parceiros. Os objetivos são sugerir a possibilidade de variações culturais, enfatizar as diferentes medidas e seus significados, e os parâmetros de H/S. Em nenhum caso estudado até agora H/S representou mais de metade do total de homicídios, nem menos de $5 \%$. 


\section{FIGURA IX}

Percentagem de H/S sobre homicídios - Quebec sobre o total de cônjuges mortos; Toyama e Grã-Bretanha sobre o total de homicídios; Carolina do Norte sobre o total de esposas e companheiras mortas; Austrália sobre homicídios entre parceiros sexuais

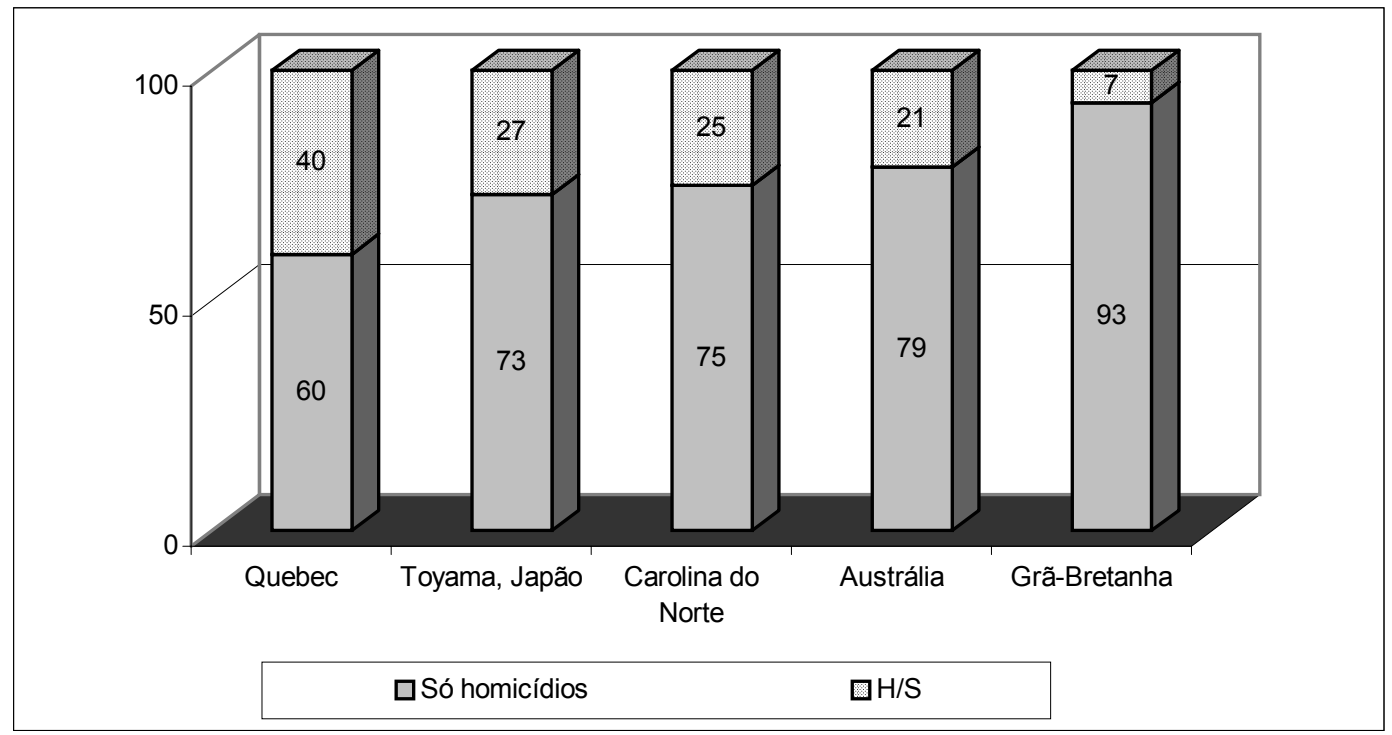

\section{Homicídios como suicídios estimulados}

Alguns homicídios, particularmente homicídios "legais"6, são suicídios disfarçados. Van Wormer et al (1999) usaram o arcabouço psicológico dos H/S para concluir que parte dos homicídios são, de fato, H/S: os assassinos matariam, em parte, esperando ser executados. Segundo os autores, em vinte e dois casos dos que eles examinaram haveria primazia do suicídio. Os autores propõem que alguns casos sejam denominados de suicídio/homicídio e não de H/S, na hipótese de que o impulso maior seria o suicida. Esses resultados são confirmados pelos de outra pesquisa de 15 mortes de pessoas com vocação suicida nos estados da Flórida e de Oregon. Essas pessoas claramente provocaram policiais, terminando por ser mortas por eles. Dois terços usaram reféns. Todos tinham algum tipo de arma e a exibiram, ameaçando os policiais ou outras pessoas. Sessenta por cento usaram a arma para ferir terceiros. Todos resistiram à prisão. Quarenta por cento tinham história documentada de diagnóstico psiquiátrico e 60\% tinham um histórico nessa direção, sendo que depressão e dependência química eram os diagnósticos mais comuns. Dos 15, 14 eram homens; dos 15, 13 eram brancos. Na opinião dos estudiosos,

\footnotetext{
${ }^{6}$ Em que os autores são policiais etc em ações legítimas, assim como outras situações também legítimas.
} 
essas pessoas queriam ser mortas pela polícia, gerando a expressão "suicídio pela polícia" (Wilson et al, 1998).

Há alguns casos em que rampage killers - pessoas que se armam até os dentes e matam várias pessoas numa série de ações consecutivas, ou matam várias pessoas no mesmo local - se suicidam; há outros em que seu comportamento desafiante, de enfrentamento com a polícia, poderia ser qualificado como "suicídiohomicídio", para usar a expressão de Wormer e colaboradores ${ }^{7}$.

\section{Estudos históricos e comparativos}

São poucos os estudos históricos e comparativos de H/S. As estatísticas criminais são menos precisas quando se tornam necessárias informações sobre as relações entre vítima e autor. Em alguns casos, não há alternativa viável a trabalhar com fontes menos confiáveis. Danson e Sotthill (1996), desejando estudar H/S no tempo, usaram os artigos publicados no "The Times", jornal Iondrino. Acompanharam 142 casos de H/S de 1887 a 1990. Os autores reconhecem os problemas da fonte, mas insistem que há padrões relacionais claros. Confirmando o encontrado em outros casos, H/S é um fenômeno em grande medida familiar e entre íntimos. Todos os casos de H/S cujas autoras eram mulheres foram entre íntimos. As taxas de H/S seriam mais elevadas entre 1887 e 1910, mas problemas de amostragem tornam suspeita qualquer estimativa de parâmetros. Os pesquisadores notam que os métodos de suicídio mudaram e que cortar a própria garganta desapareceu como método a partir da década de 20. As armas de fogo, neste estudo como em outros, passaram a ser dominantes, particularmente entre homens.

A maioria das interpretações de H/S se limita a seus aspectos interativos, situacionais e oportunistas. Não obstante, um estudo de cunho histórico liga uma "onda" de H/S que teria havido em Chicago entre 1875 e 1910 a problemas derivados de interações entre covariatas estruturais e culturais. Adler examinou os artigos de jornal e os processos policiais do período, concluíndo que as relações entre gênero e as ideologias a respeito delas estavam em mudança rápida, resultando em H/S quando, em outras circunstâncias, terminariam em homicídios ou suicídios. Adler (1999) prefere explicações estruturais e valorativas, enfatizando as interações entre forças estruturais e culturais. Os autores eram, predominantemente, homens, jovens, um pouco mais pobres, e mais dispostos a usar armas de fogo do que os que somente se suicidaram. A perspectiva históricosocial de Adler deixa implícito que fatores pessoais e psicológicos atuam dentro da moldura de estruturas sociais e da cultura. O impacto das variáveis psicológicas e

\footnotetext{
${ }^{7}$ É interessante que, até agora, nenhum dos rampage killers jovens e adolescentes, que usualmente matam colegas e professores, se suicidou. Os suicídios e os suicídios pela polícia só caracterizam rampage killers adultos.
} 
psiquiátricas não seria independente dessas estruturas. Adler trabalha claramente dentro de um paradigma durkheimiano, enfatizando a mudança e a dificuldade de muitas pessoas em acompanhá-la.

Milroy (1995) focalizou os aspectos comparativos de H/S (e de homicídio). Chegou à interessante conclusão de que as taxas de H/S por 100 mil habitantes variavam muito entre os países mas que, dentro de cada país, o fenômeno seguia o mesmo padrão dos outros países: o autor era, usualmente, um homem, matando a esposa ou companheira e, com menos freqüência, as crianças, motivado por ciúme ou desejo de vingança, num momento de separação ou pouco após uma separação, usando arma de fogo.

Repito que um estudo de homicídio/suicídio necessita que sejam estudadas as características das vítimas, dos agressores, das relações entre eles e das circunstâncias. Foi o que fizeram Cooper e Eaves (1996) no Canadá (no Sudoeste do Estado de British Columbia). Examinaram dados de fontes múltiplas - o exame médico-legal, os arquivos da polícia, dados forenses e dados disponíveis nas comunidades sobre a saúde mental das pessoas - a respeito de 148 vítimas em 124 atos homicidas ocorridos entre 1984 e 1992. Infelizmente, estudaram apenas os homicídios/suicídios na família, definida como aquelas situações nas quais vítima e assassino tinham relações afetivas e/ou de parentesco. Segundo os autores, influenciados por teorias evolucionistas, H/S aconteceram sobremaneira devido à apropriação masculina de outras pessoas - que se manifestaria no assassinato de ex-parceiras sexuais e/ou suas filhas e filhos, após uma separação íntima, ou então por doença mental. Em contraste, nenhum dos homicídios que ocorreram como resultado de violência das vítimas (comuns no assassinato de homens por parceiras), de abuso de crianças, de conflitos familiares, por motivos financeiros ou por motivos criminais/financeiros, levou ao suicídio do assassino.

\section{Explicações psicológicas}

Banzato (1990) descreveu os casos de um homem de 43 anos e uma mulher de 32 que tentaram matar seus filhos e cometer suicídio. Os dois sofriam de depressão e o autor enfatiza uma perspectiva psicanalítica ao relacionar a depressão com o filicídio. Evidentemente, um problema com estudos baseados em pequenos números é o de representatividade. Para que os resultados fossem generalizáveis, seria necessário que a população de pais e mães que tentam o filicídio e depois o suicídio fosse homogênea, o que, de antemão, sabemos que não ocorre.

Os mesmos problemas se aplicam ao trabalho de Lavergne e Lavergne (1990), que discutem o caso de um homem de 34 anos que matou suas duas filhas 
menores durante o seu divórcio. Os autores enfatizam a história de suicídio e depressão na família, relativizando a responsabilidade penal do autor.

Não há dúvida de que doenças mentais, particularmente a depressão (talvez por ser comum), contribuem para a explicação de H/S. O que falta é saber qual o seu lugar num esquema inter-disciplinar de explicação dos homicídios-suicídios.

Iga Mamoru (1996) apresenta uma equação complexa, ao analisar o "oyako shinju", que se refere, na cultura local, ao suicídio de pais e filhos(as), mas que, fora dessa cultura, é definido como H/S. Mamoru enfatiza o papel dos "recursos sociais", de que indivíduos dispõem em diferentes medidas, para reduzir tensões, conflitos, estresse e para resolver problemas. Mamoru conclui que os significados sociais atribuídos ao suicídio e outras formas de comportamento auto-destrutivo (e, acrescento, H/S) só são captados através de estudos de personalidade, individualizados, no contexto em que se realizam.

Houve, na Suécia, 96 assassinatos de menores de 15 anos durante um período de dez anos (1971-1980), uma taxa anual de 0,6 por cem mil crianças. Apesar de baixíssima, por padrões brasileiros, preocupa as autoridades e os pesquisadores suecos. Somander et al (1991) estudaram esses casos, concluindo que a maioria era intra-familiar, freqüentemente seguida pelo suicídio de um dos pais, e que a maioria das vítimas era de tenra idade, crianças pequenas. 0 padrão difere de outros, porque os casos de abuso de crianças por um/ambos pais e de abuso sexual eram poucos, mas segue a maioria, uma vez que 37 dos 47 autores examinados apresentavam sintomas de doença mental - 79\%.

Cormier e colaboradores (1971) propuseram um esquema interpretativo baseado nas gratificações derivadas dos relacionamentos e interações humanas. Afirmam que os assassinatos com freqüência derivam de relações intensas entre autor e vítima. Essa afirmação reflete a infreqüência de H/S entre desconhecidos no Canadá. Criminosos de carreira, afirmam, têm poucos laços pessoais fortes e significativos, e a hostilidade deles se atomiza na sociedade como um todo, sem se concentrar em poucas pessoas significativas. Já as maiores frustrações do cidadão cumpridor das leis se originam exatamente das pessoas que ele mais ama. Mais uma vez, aparece a influência do contexto em que os autores escrevem: a desigualdade da sua sociedade é aceitável, assim como o funcionamento das instituições.

Dentro desses parâmetros, a lógica dos autores é convincente: quando alguns desses fortes conflitos aparecem, alguns desenvolvem um desejo de destruir a sua origem e um número menor pode chegar a fazê-lo num momento de descontrole. Os autores vêem o assassinato numa relação como um problema de coexistência. Em muitos casos, a relação é intolerável, mas a separação parece impossível. Essa situação caracterizaria, em particular, os casos de homicídio/suicídio. O assassino mata alguém que não quer perder e o suicídio 
subseqüente seria uma forma de viver a fantasia da reunião com o objeto que perdeu.

Stanton et al (2000) estudaram intensamente seis mulheres que mataram seus(suas) filhos(as) na Nova Zelândia, através do psiquiatra delas. Eram mulheres que "mataram no contexto de doenças mentais sérias". A metodologia se baseou nas entrevistas, que foram gravadas, transcritas, codificadas e analisadas. 0 tempo transcorrido entre as mortes e as entrevistas é relevante: variou entre 12 e 23 anos. Eram, portanto, experiências distantes no tempo. As impressões se concentraram na maternidade, que foi descrita pelas autoras como requerendo muito tempo e esforço, nos fatores externos de estresse, que não pareceram muito intensos, e na experiência com a doença mental, que foi descrita como estressante. As filicidas disseram que houve pouco ou nenhum planejamento. As descrições que apresentaram dos seus(suas) filhos(as) não tinham nada de extraordinário. A motivação descrita se baseava no altruísmo ou num pacote que incluía o suicídio. As mulheres apresentaram culpa e remorso, mesmo sabendo que sofriam de doença mental séria.

As pesquisadoras sublinham a dificuldade em identificar sintomas de perigo em mulheres que não dão indicações de que podem cometer filicídio. Argumentam que esse tipo de homicida (mas não outros) seria melhor compreendido em termos da sua doença mental específica do que a partir de fatores de estresse externos individuais ou de psicodinâmica. O problema, mais uma vez, reside na insuficiência da amostra.

George Palermo (1994) propõe uma nomenclatura e uma explicação diferentes com base numa avaliação em que combina perspectivas psicanalíticas e psiquiátricas com dados sociológicos. Para Palermo, H/S seria melhor entendido se fosse chamado de "suicídio ampliado". Palermo enfatiza a exarcebação do ciúme por traços paranóicos e define o(a) autor(a) como essencialmente frágil, mas também dependente, ambivalente e agressivo(a). A auto-afirmação e a dureza seriam fachadas, sob as quais se esconderia uma pessoa débil, incapaz de enfrentar uma rejeição inesperada ou uma mudança radical na vida. Tal pessoa comete o suicídio após matar a extensão de si mesmo(a).

Essa classificação foi refinada e usada em um estudo de homicídios intrafamiliares na África do Sul, entre 1978 e 1987, publicado por R. Graser em 1992. O estudo usou os inquéritos policiais e os processos judiciais, jornais e entrevistas com parentes e sobreviventes. Em sua maioria, os autores de $\mathrm{H} / \mathrm{S}$ matavam ou tentavam matar suas vítimas durante o dia, usualmente depois de uma altercação, discussão ou briga, e de maneira explosiva, não planejada. Os autores de "suicídio ampliado", ao contrário, frequentemente matavam suas vítimas metodicamente, uma a uma, quando elas dormiam. 
Não obstante, as explicações de Graser não começam com a psicologia do autor: começam com macrocovariatas e passam pela psicologia e pela psiquiatria. Sublinham que todos os autores estavam socialmente isolados, sem contatos nem recursos sociais - baixo capital social. Metade estava desempregada e os assassinatos eram mais comuns em pequenas comunidades. Graser sublinha o isolamento dos autores dentro da sociedade e dentro da família. Graser não deixou os aspectos situacionais de fora: sublinhou que, além do isolamento social, vários eventos parecem ter tido efeitos cumulativos: problemas maritais, problemas financeiros, problemas com drogas e alcoolismo, e doenças, inclusive doenças mentais. A questão essencial do instrumento também é incorporada: as armas de fogo dominaram o cenário.

Cohen et al (1998) examinaram, também, H/S em 7 condados da Flórida no período 1988-1994. Usaram os relatórios forenses dos "medical examiners". Codificaram nada menos do que 160 variáveis. Concordam com a percepção de que $\mathrm{H} / \mathrm{S}$ resulta de uma série de efeitos aditivos ou multiplicativos, que incluem cultura e experiências estressantes. Os H/S de cônjuges, parceiras e namoradas foi o mais comum. Agregam, às variáveis explicativas já conhecidas, mais um: casais mais velhos (acima de 55 anos) tinham uma taxa mais alta de $\mathrm{H} / \mathrm{S}$, que variava de 0,4 a 0,9 por 100 mil pessoas, ao passo que os mais jovens (com menos de 55 anos), tinham taxas que variavam de 0,3 a 0,7 entre os condados.

O caráter cultural das explicações aparece no estudo de Toyama, no qual uma quarta parte dos homicidas tinha problemas mentais. Infelizmente, os dados publicados não permitem distingüir entre a percentagem com problemas mentais em H/S e em homicídios.

O estudo de Silverman e Kennedy, sobre mulheres canadenses que mataram os seus filhos, gerou algumas indagações. O diagnóstico nos diz que $67 \%$ das mães que mataram filhos e filhas crianças ou adolescentes apresentavam doença mental, em comparação com $36 \%$ das mães que mataram bebês. A que se deve essa diferença?

- Os critérios científicos foram observados e são independentes de definições (e pressões) culturais;

- Os critérios científicos são dependentes de definições culturais e matar bebê é visto como "menos anormal" que matar um(a) filho(a) mais velho;
- Os critérios são corretos, mas os que fizeram os diagnósticos foram influenciados por definições culturais ou

- Combinações dessas e outras causas, com peso desconhecido? ${ }^{8}$

\footnotetext{
${ }^{8}$ Dados de Silverman Robert A; Kennedy Leslie W. “Women who kill their children” Violence and Victims, 3, (2), 1988, págs. 113-127.
} 
Rosembaum (1990) pesquisou o papel da depressão entre vítimas e autores em 24 casos de homicídios e 12 de H/S em casais. As conclusões apoiam outros estudos e, a despeito do pequeno número de casos, podem ser consideradas como evidência secundária. Três em cada quatro dos autores de H/S estavam deprimidos, em contraste com nenhum dos autores de homicídios. Entre as vítimas o padrão se inverte: a maioria das vítimas de homicídio apresentava desordens de personalidade, dependência química e patologia social, mas nenhuma das 11 mulheres vítimas de H/S apresentava sintomas sérios. A confirmação desse estudo por pesquisas com amostras maiores aleatórias permitirá concluir que tanto autores quanto vítimas em homicídios e em H/S diferem, caracterizando-os como fenômenos psicologicamente diferentes.

\section{FIGURA X}

Diagnóstico de doença mental por tamanho/idade das vítimas - Mulheres canadenses que mataram seus(suas) filhos(as) - 1961 a 1963

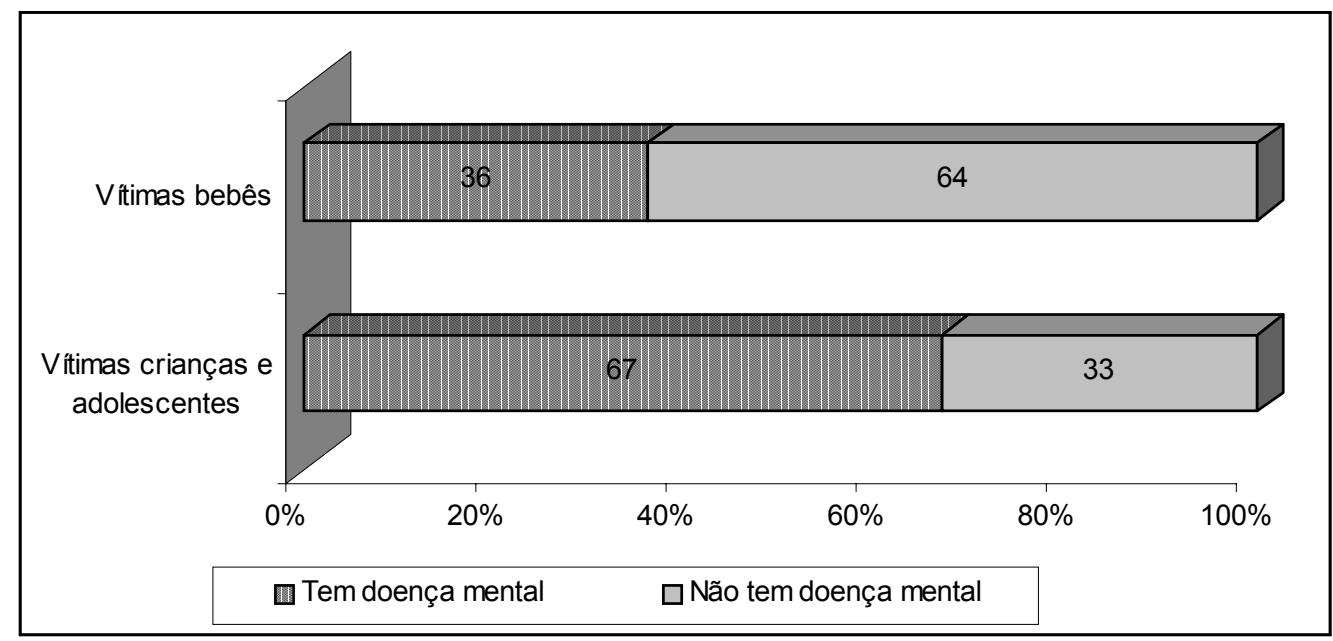

Malphurs et alii compararam 27 homens que mataram as esposas na parte central da Flórida, e que depois se suicidaram, com 36 também casados e que se suicidaram, mas que não mataram a esposa. Metade dos que mataram a esposa estavam cuidando dela, devido a doença ou invalidez, em comparação com apenas $17 \%$ dos que se suicidaram. Havia, entre os que se suicidaram sem matar, uma percentagem mais alta de pessoas com problemas de saúde. Os dois grupos tinham uma alta percentagem de homens com depressão, ainda que nenhum tivesse sinais de anti-depressivos na necrópsia. 
Lecso (1989) analisou um caso de um paciente com Alzheimer. O homem, de 67 anos, também tinha uma história de violência, dependência química e doença mental. Matou a mulher que vivia na mesma casa, sob a alegação de que ela roubava o cheque da sua aposentadoria. Não há, na literatura sobre homicídios e sobre H/S, menções a Alzheimer comensuráveis com a sua importância na literatura geriátrica. Além disso, o uso de drogas, a história de violência e de outras doenças mentais colocam em dúvida a causa do homicídio.

A revisão de Felthous et al mostra a variedade de explicações e variantes de cunho psicológico ou psico-social:

- Debilidade do ego

- Depressão

- Sociopatia

- Psicose
- Alcoolismo e abuso de outras drogas

- Ciúme e paranóia

Além disso, percorre a variedade de tipos de H/S baseados nas relações entre autor e vítima(s):

- De cônjuges e parceiras(os) sexuais

- Filicida

- Pseudo-comando e pseudo-dominação
- Familicida

- Adversária ou conflitiva

- De cultos

A variedade de explicações e de tipos nos mostra uma realidade assaz mais complexa do que "H/S é um crime no qual alguém mata alguém mais e se suicida".

\section{Efeito Werther em $\mathrm{H} / \mathrm{S}$ ?}

No que concerne à prevenção, o papel da mídia é uma incógnita. Há "epidemias" de suicídios que não chegam a alterar drasticamente as taxas nacionais; fala-se de uma grande epidemia entre homens jovens após a publicação de "As desventuras do jovem Werther". A mídia no Brasil acolheu a posição prudente de não enfatizar os suicídios. Como saber se há influência, quão forte e em que direção?

Steven Stack (1989) estudou este problema, mas o enfocou em casos nos quais o assassino mata várias pessoas e se suicida, e nos casos de assassinatos múltiplos que foram noticiados. O resultado desaconselha a divulgação ampla: A taxa de homicídios não foi afetada pela divulgação de assassinatos múltiplos/suicídios, mas a taxa de suicídios aumentou significativamente. Um tipo especial de assassinatos múltiplos, o efetuado por gangues contra gangues, também aumentou a taxa de suicídios. Stack controlou fatores estacionais e os 
preditores econômicos de agressão e violência. Seus dados são mensais, de 1968 a 1980.

A política informal da mídia brasileira de não glorificar atos violentos, particularmente o suicídio, é sensata. Há indicações de certo efeito-contágio, ou efeito-Werther no que concerne aos suicídios. Uma altíssima percentagem das pessoas que tentaram suicídio a sério e escaparam se arrependeu do que fez e teve vidas produtivas e felizes, a despeito de que, estatisticamente, quem já tentou o suicídio tem mais alta probabilidade de voltar a fazê-lo do que quem nunca tentou.

\section{Os sinais de perigo e a prevenção de $H / S$}

H/S dá freqüentes sinais de que pode acontecer. O estudo de Morton et al (1998) permite ver quais são eles.

\section{FIGURA XI}

Prenúncios imediatos de H/S - Carolina do Norte, 1988 a 1992

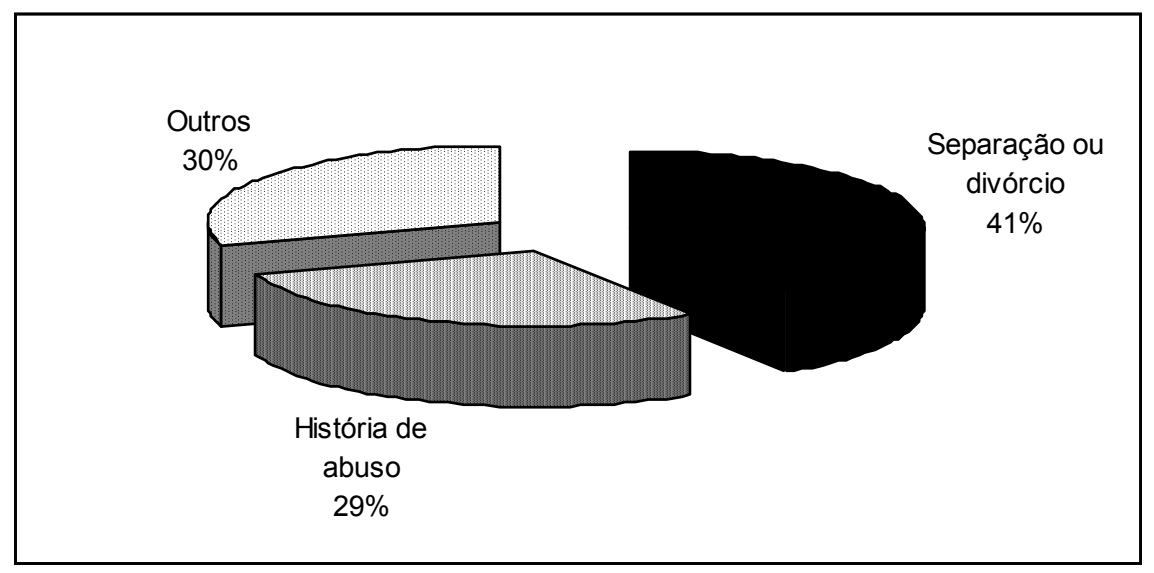

Casais, em união legal ou consensual, que estão em fase de separação ou pouco tempo após a separação apresentam a mais alta probabilidade de H/S - e de uxoricídio também. Pelo fato de os uxoricídios serem mais freqüentes do que H/S, há informações mais abundantes a respeito deles. Quatro em dez casos estavam nessa fase. Uma história de abuso e de violência estava presente em 29\% dos casos estudados por Morton. Esse é, também, um fator presente em muitos casos de uxoricídio e de filicídio. Um número de mortes advém no curso de surras e pancadas. Portanto, nossa atenção preventiva deve enfocar esses fatores de risco: um histórico de violência no casal (ou nas relações com os filhos e enteados) e o período pré e pós-separação. Tudo indica que a probabilidade de H/S, assim como de uxoricídio e de filicídio, diminui após certo tempo de separação. 
Bailey e Banton (1997) também estudaram os fatores de risco de mortes violentas de mulheres em casa. Seus dados foram obtidos, na medida do possível, através de entrevistas com outras pessoas vinculadas às vítimas. Entrevistaram essas pessoas vinculadas (proxy respondents) em $80 \%$ dos 554 casos de suicídio e em $93 \%$ dos 420 casos de homicídio. Usaram tres condados, cada um em um estado diferente. Os dados cobrem o período de 1987 a 1992. Os autores entrevistaram também um número de pessoas com características sócio. demográficas semelhantes às das vítimas.

A violência doméstica surgiu como o principal fator de perigo no caso de homicídios na casa, nos casos em que o autor era o cônjuge, um familiar ou um amigo íntimo. A presença de armas de fogo também aumentava significativamente a probabilidade de homicídio em casa. Um quarto dos assassinos "íntimos" se suicidou após o homicídio. A probabilidade de homicídios por estranhos ou conhecidos não-íntimos aumentava no caso de mulheres que viviam sozinhas ou cujos companheiros tinham ficha policial. É esperado que uma população de companheiros(as) com ficha na polícia tenha um conjunto de amigos e conhecidos mais dispostos ao crime. A maioria desses homicídios estava vinculada a outro crime, em geral contra a propriedade.

Outra pesquisa enfatiza mais a motivação e não os fatores de risco, mas as conclusões são consistentes com as anteriores. Ciúme e vingança, sobretudo numa situação de separação ou divórcio, seriam as principais motivações (Milroy, 1995)

H/S é um fenômeno típicamente doméstico: raramente começa e termina fora de casa.

Há um elemento de "oportunidade" em H/S. Muitas relações nas que há abuso poderiam terminar em homicídio, tal a violência do abuso. Porém, algumas terminam e muitas não. O comportamento típico do agressor após o homicídio doméstico não é se suicidar, mas alguns o fazem. Assim, há um elemento de indeterminação em alguns $\mathrm{H} / \mathrm{S}$ e em alguns que não chegaram a se transformar em homicídios nem portanto, em H/S.

A característica "doméstica" de H/S torna a prevenção mais difícil: as residências estão em todas as partes, ao passo que o mapeamento do crime urbano nos informa que uma altíssima percentagem do crime, inclusive do crime violento, ocorre em menos de dez por cento da área urbana. O vetor dominante da prevenção, portanto, pode ser geográfico-espacial no que concerne ao crime, mas não no que concerne a H/S. Não obstante, sabemos que a violência doméstica é um dos grandes sinais de perigo de H/S. Ela dá sinais, deixa pistas. A medida preventiva principal é que as autoridades aprendam a reconhecer esses sinais e a agir em função deles. Casais, em matrimonio ou união consensual, com histórico de violência, estão em situação de risco, particularmente as mulheres, secundariamente as crianças. O período que cobre a ruptura e a separação física, 
até um mínimo de um ano depois, é o de maior perigo. O abuso de álcool e outras drogas, e a presença de doença mental multiplicam a probabilidade de violência, inclusive de H/S. A presença de arma de fogo na casa também multiplica - e muito - a probabilidade de todos os tipos de violência letal: homicídios, suicídios, H/S e acidentes.

H/S com vítimas menores de idade requer tanta atenção com as mães quanto com os pais. O homicídio doméstico simples requer maior atenção com padrastos e madrastas. Mulheres vivendo sós, com problemas financeiros e com depressão, apresentam maior risco de filicídio. Essa informação com freqüência existe fora da casa, entre outros familiares, amigos e vizinhos, mas não chega às autoridades públicas. A prevenção que existe é feita por agentes informais, vinculados às pessoas. Mas essas pessoas não têm poder para prender nem para receitar anti-depressivos.

Numa sociedade desarticulada e/ou com um governo sem capacidade de resposta, esses sinais existem, mas não constam da memória do governo. Quando são registrados, raramente há ação. A melhoria dos serviços públicos na área da prevenção da violência doméstica é, portanto, essencial. A coleta de informações, que é péssima, pode ser melhorada com uma polícia com orientação comunitária que, graças às boas relações com a comunidade, tem acesso a informações antes indisponíveis. Os vários setores públicos devem se comunicar - hospitais, assistentes sociais e polícia.

Essa tarefa de prevenção também requer que a comunidade de cientistas sociais - que receberam, na maioria dos casos, sua educação grátis e até com bolsas - devolvam à sociedade parte desses benefícios na forma de conhecimento útil, realizando pesquisas com o objetivo de melhorar as condições de vida da população.

Não temos informações sobre H/S no Brasil. Como não há pesquisas, não há dados sistematizados. Conhecer é o primeiro passo da mudança para melhor, e mudança, em homicídios-suicídios, se paga ou se recebe em vidas e em dobro.

\section{BIBLIOGRAFIA}

ADERIBIGBE Yekeen A. (1997) Violence in America: a survey of suicide linked to homicides. Journal of Forensic Sciences, 42 (4):662-665.

ADLER Jeffrey S. (1999) 'If we can't live in peace, we might as well die'-- homicide-suicide in Chicago, 1875-1910. Journal of Urban History, 26 (1): 3-21.

ANDREW F. Henry \& SHORT JR, James F. (1954) Suicide and homicide; some economic, sociological, and psychological aspects of aggression. Glencoe, III., Free Press.

BAILEY, James E \& BANTON, Joyce G. (1997) Risk factors for violent death of women in the home. Archives of Internal Medicine, 157: 777-782. 
BANZATO, Claudio E. (1990) Depressão y filicídio. Jornal Brasileiro de Psiquiatria.; 39(6): 301-306. (Nov-Dec)

BERMAN, Alan L. (1996) Dyadic death: A typology Suicide and Life Threatening Behavior. 26(4): 342-350.

CHEW, Kenneth SY; MCCLEARY, Richard; MARICRES, Lew A, et. al. (1999) The epidemiology of child homicide in California, 1981 through 1990. Homicide Studies, 3(2):151-169.

COHEN, Donna; LLORENTE, Maria \& EISDORFER, Carl (1998) Homicide-suicide in older persons. American Journal of Psychiatry. 155(3): 390-396. (Março)

COOPER Mary \& EAVES, Derek (1996) Suicide following homicide in the family. Violence and Victims, 11(2): 99-112.

CORMIER, Bruno M; et. al. (1971) The psychodynamics of homicide committed in a specific relationship. Canadian Journal of Criminology and Corrections Ottawa, 13(1): 1-8.

DALY, Martin \& WILSON, Margo. (1987) Children as homicide victims. In: GELLES, Richard J. \& LANCASTER, Jane B. (orgs.) Child Abuse and Neglect: Biosocial Dimensions. New York, Aldine De Gruyter, p.201-214.

DANSON, Linda \& SOTTHILL, Keith. (1996) Murder followed by suicide: a study of the reporting of murder followed by suicide in The Times 1887-1990. The Journal of Forensic Psychiatry, 7(4):310322.

EASTEAL, Patricia. (1994) Homicide between adult sexual intimates in Australia: implications for prevention. Studies on Crime and Crime Prevention, 3:24-40.

FELTHOUS, Alan R \& HEMPEL, Anthony. (1995) Combined homicide-suicides: A review. Journal of Forensic Sciences. 40(5): 846-857 (setembro).

FISHBAIN, David A; RAO, Valerie J \& ALDRICH, Tim E. (1985) Female homicide-suicide perpetrators: a controlled study. Journal of Forensic Sciences, 30(4):1148-1156.

GILLESPIE, Michael; HEARN, Valerie \& SILVERMAN, Robert A. (1998) Suicide following homicide in Canada. Homicide Studies, 2 (1):46-63.

GRASER, R. R. A study of selected cases of family murder in South Africa.

HAAPASALO Jaana \& PETAJA, Sonja. (1999) Mothers who killed or attempted to kill their child: life circumstances, childhood abuse, and types of killing. Violence and Victims, 14(3):219-239.

IGA, Mamoru. (1996) Cultural aspects of suicide: The case of Japanese oyako shinju. Archives of Suicide Research. 2(2): 87-102.

LAVERGNE, M P \& LAVERGNE, T. (1990) Un pere meurtrier de ses deux filles. Information Psychiatrique. 66(7): 669-676 (setembro).

LECOMTE D. \& FORNES, P. (1998) Homicide followed by suicide: Paris and its suburbs, 19911996. Journal of Forensic Sciences , 43(4):760-764.

LECSO, Philip A. (1989) Murder-suicide in Alzheimer's disease. Journal of the American Geriatrics Society. 37(2): 167-168 (fevereiro).

MEMMOTT, Paul, STACY, Rachael, CHAMBERS, Catherine, et. al. (2001) Violence in indigenous communities. Austrália.

MILROY C.M. (1995) The epidemiology of homicide-suicide (dyadic death). Forensic Science International, 71:177-122. 
MORTON, Emma; RUNYAN, Carol W; MORACCO, Kathryn E. \& BUTTS, John. (1998) Partner homicide-suicide involving female homicide victims: A population based study in North Carolina, 1988-1992. Violence and Victims. 13(2): 91106.

PALERMO, George B. (1994) Murder-suicide--an extended suicide. International Journal of Offender Therapy and Comparative Criminology, 38(3):205-216.

ROSENBAUM, Milton. (1990) The role of depression in couples involved in murder-suicide and homicide. American Journal of Psychiatry, 147(8):1036-1039.

SILVERMAN, Robert A. \& KENNEDY, Leslie W. (1988) Women who kill their children. Violence and Victims, 3(2):113-127.

SOMANDER, Lis K. \& RAMMER, Lennart M. (1991) Intra- and extrafamilial child homicide in Sweden 1971-1980. Child Abuse and Neglect, 15 (1/2):45-55.

STACK, Steven. (1997) Homicide followed by suicide: an analysis of Chicago data. Criminology, 35(3):435-453.

(1989) The effect of publicized mass murders and murder-suicides on lethal violence, 1968-1980: A research note. Social Psychiatry and Psychiatric Epidemiology. 24(4): 202208 (julho).

STANTON Josephine, SIMPSON, Alexander \& WOULDES, Trecia. (2000) A qualitative study of filicide by mentally ill mothers. Child Abuse and Neglect, 24(11):1451-1460.

STEVENSON M.R., WALLACE, L.J.D., HARRISON J, MOLLER, J. \& SMITH, R.J. (1998) At risk in two worlds: injury mortality among indigenous people in the US and Australia, 1990-92 Australian and New Zealand Journal of Public Health, 22(6): 641-4 (outubro).

VAN WORMER, Katherine \& ODIAH, Chuk. (1999) The psychology of suicide-murder and the death penalty. Journal of Criminal Justice, 27(4):361-370.

WILSON, Edward F., DAVIS, Joseph H., BLOOM, Joseph D, et. al. (1998) Homicide or suicide: the killing of suicidal persons by law enforcement officers. Journal of Forensic Sciences, 43(1): 46-52.

WILSON Margo, DALY, Martin \& DANIELE, Antonietta. (1995) Familicide: the killing of spouse and children. Aggressive Behavior, 21:275-291. 